\title{
An Analysis of Patents Filed at African Regional Intellectual Property Organisation (ARIPO) from January 2015 to December 2016 for Research Intelligence Signalling Using Open Source Patent Analytics
}

\author{
Gabriel Muzah \\ College of Business, Peace, Leadership and Governance, Africa University, Mutare, \\ Zimbabwe \\ muzahg@africau.edu; gmuzah@yahoo.co.uk
}

\begin{abstract}
This paper analyses 949 patents filed at African Regional Intellectual Property Organisation (ARIPO) from January 2015 to December 2016 using Google Sheets and Tableau Public for research intelligence signalling. The results show that the highest number of patent applications was filed by Qualcomm Incorporated followed by Bayer Pharma Aktiengesellschaft. In the universities and research institutions space the highest number of applications came from South African institutions. Nearly 50 percent of the total patent applications came from applicants who filed for a single patent. An analysis of the International patent Classification shows that a majority of applications (12.8 percent) were classified in the heterocyclic compounds (C07D) field. Patent information is critical for research intelligence signalling as it provides a rapid assessment of the state of the art and avoids duplication. It also assists in identifying existing work on which to build on, valuable research topics, potential research collaborators and potential industry partners.
\end{abstract}

Keywords: Patents, Open Source Patent Analytics, Research Intelligence

\section{Introduction}

The world has recently witnessed a rapid expansion of access to technology information as a result of the increasing availability of technical documents in digital format and the progressive development of electronic means of distribution and retrieval [1]. It is generally accepted that a significant volume of technical and scientific information is only available through patent publications by national, regional and international intellectual property administration offices [2]. The African Regional Intellectual Property Organisation (ARIPO) is one such office which has recently digitised its patent documents. The challenge that arises from such an endeavour is the ability to find relevant information from which useful knowledge can be extracted [3]. Patent information is critical for research intelligence signalling as it provides a rapid assessment of the state of the art and 
avoids re-inventing the wheel. It also assists in identifying existing work on which to build on, valuable research topics, potential research collaborators and potential industry partners [4]. This paper aims at analysing patents filed at ARIPO from January 2015 to December 2016 for research intelligence signalling using open source patent analytics. The main objective of this paper is to raise awareness of the importance of patent literature as a resource for researchers.

Research intelligence signalling is based on the classic question, "Are inventions knowledge induced or demand induced [5]?" Empirical evidence has demonstrated the close links at the industry level between investment in fixed assets and successful patent applications, making an invention a response to market opportunities $[6,7,8]$. The direction and pace of such depend on previous inventions which establish the necessary technological preconditions for the development of some new product or process as well as shape tastes and preferences for the developments which should follow thus making patent literature a critical signalling component. A test of the usefulness of the patent literature as a source of technical information was carried out in 1971 by the Assistant Secretary of Commerce for Science and Technology in United States of America after recognising that the potential of the patent literature as a technological resource was not being fully utilised. The study recommended: "Following an exhaustive parallel search by the Patent and Trademark Office, and UOP, Inc. on specific technology, the ACS Committee on Patent Matters and Related Legislation has found that industry apparently does not make adequate use of the Patent and Trademark Office files as an information source. Therefore, the American Chemical Society urges greater availability, in usable form, of Patent and Trademark Office records in other geographical areas for more convenient access to this national resource [9]." In recent times, patent literature has been widely used for understanding technological change. According to Benson CL, Magee CL (2015), patents are an attractive choice for analyzing technological change because they are: generalisable, objective, quantitative and qualitative. Patents include many technical fields over a long period of time, and thus allow for easier generalisation of the research. There are specific criteria for an invention to be patented, which creates an objective standard as to what counts as an invention (as opposed to a subjective list of innovations in a field). Each patent is well tracked and includes a wealth of meta-data, and thus allows for quantitative analysis [10].

A patent can be described as an intellectual property right or a form of a document. As a form of intellectual property right, a patent is exclusively granted by a sovereign state to the owner preventing others from making, using, offering for sale, or importing without their consent for a certain period of time, usually twenty years, in exchange for disclosure of technical information. This disclosed information is published by an intellectual property office as a type of document also referred to as a patent. The patents published by the ARIPO Journal, a quarterly publication published by ARIPO, contain data types identified by codes universally known as internationally recognised numbers for the identification of data (INID) codes. These are provided for by the World Intellectual Property Organisation (WIPO) Standard ST. 9 (Recommendation concerning bibliographic data on and relating to patents and supplementary protection certificates[SPCs]) which is aimed at improving the access to information relating to patents and SPCs in general and to the bibliographic content 
An Analysis of Patents Filed at African Regional Intellectual Property Organisation (ARIPO) from January 2015 to December 2016 for Research Intelligence Signalling Using Open Source

Patent Analytics 3

of Patent Gazettes and patent documents in particular [11]. See Table 1 for INID codes for patents.

Table 1. INID Codes for Patents

\begin{tabular}{|c|c|c|c|c|c|}
\hline $\begin{array}{l}\text { INID } \\
\text { Code }\end{array}$ & Interpretation & $\begin{array}{l}\text { INID } \\
\text { Code }\end{array}$ & Interpretation & $\begin{array}{l}\text { INID } \\
\text { Code }\end{array}$ & Interpretation \\
\hline$(11)$ & Patent Number & $(33)$ & $\begin{array}{l}\text { Convention country / } \\
\text { Convention } \\
\text { organization }\end{array}$ & $(73)$ & $\begin{array}{l}\text { Name(s) of holder(s) of } \\
\text { patent or patentee's } \\
\text { name. If in } \\
\text { announcements } \\
\text { concerning "Patent } \\
\text { Applications Assigned" } \\
\text { or "Patents Assigned", } \\
\text { this code represents the } \\
\text { name of the assignor } \\
\text { (or the name of the } \\
\text { current owner of the } \\
\text { patent application or } \\
\text { the name of the current } \\
\text { owner of the patent) }\end{array}$ \\
\hline 21) & Application Number & $(45)$ & Date of Publication & (74) & Attorney's name \\
\hline (22) & Filing Date & (51) & $\begin{array}{l}\text { Symbol of the } \\
\text { International Patent } \\
\text { Classification (IPC) }\end{array}$ & $(75)$ & $\begin{array}{l}\text { Name(s) of inventor(s) } \\
\text { who is/are also } \\
\text { applicant(s) }\end{array}$ \\
\hline (23) & $\begin{array}{l}\text { Date when action is to } \\
\text { be taken, if in } \\
\text { announcements for } \\
\text { "Patent Applications } \\
\text { Pending Grant" ; date } \\
\text { from which status } \\
\text { takes effect, if in } \\
\text { "Applications } \\
\text { Abandoned" or in } \\
\text { "Patents Abandoned }\end{array}$ & (54) & Title of the invention & (71) & $\begin{array}{l}\text { Applicant's name. If in } \\
\text { announcements } \\
\text { concerning "Patent } \\
\text { Applications Assigned" } \\
\text { or "Patents Assigned", } \\
\text { this code represents the } \\
\text { name of the assignee } \\
\text { (or the name of the } \\
\text { new owner of the } \\
\text { patent application or } \\
\text { the name of the new } \\
\text { owner of the patent) }\end{array}$ \\
\hline (24) & $\begin{array}{l}\text { Effective Date of } \\
\text { patent }\end{array}$ & (56) & $\begin{array}{l}\text { List of prior art } \\
\text { documents cited in } \\
\text { the examination }\end{array}$ & (84) & $\begin{array}{l}\text { States designated under } \\
\text { the Harare Protocol }\end{array}$ \\
\hline (31) & Priority Number & (57) & Abstract & (86) & $\begin{array}{lr}\text { Patent } & \text { Cooperation } \\
\text { Treaty } & \text { (PCT) } \\
\text { international filing date } \\
\text { and number }\end{array}$ \\
\hline (32) & Priority Date & (72) & $\begin{array}{l}\text { Name(s) } \\
\text { inventor(s) }\end{array}$ & $(96)$ & $\begin{array}{l}\text { Harare Protocol filing } \\
\text { date and number }\end{array}$ \\
\hline
\end{tabular}

This paper is delimited to an analysis of the following data types and codes:

- Application number (21) - this is the number accorded to an application on filing.

- Applicant's name (71) - The person or company that applies for the patent and intends to "work" the invention (i.e. to manufacture or licence the technology). In most countries the inventor(s) does not necessarily have to be the applicant [12]. This information is important to researchers as it allows them to identify research collaborators and potential industry partners. 
- International Patent Classification (51) - provides for a hierarchical system of language independent symbols for the classification of patents according to the different areas of technology to which they pertain. The IPC divides technology into eight sections namely; Section A: Human Necessities, Section B: Performing Operations; Transporting, Section C: Chemistry; Metallurgy, Section D: Textiles; Paper, Section E: Fixed Constructions, Section F: Mechanical Engineering; Lighting; Heating; Weapons; Blasting, Section G: Physics, Section H: Electricity. These sections have approximately $\mathbf{7 0 , 0 0 0}$ subdivisions. Each subdivision has a symbol consisting of Arabic numerals and letters of the Latin alphabet [13]. This data assists researchers to assess of the state of the art and identify technology areas on which they can build on.

- Title of the Invention (54) - this is a technically accurate and descriptive title of the invention. The title of the invention should be meaningful, clearly, concisely and as specifically as possible indicate the subject to which the invention relates [14]. It allows researchers to identify valuable research topics and are of considerable importance to users who are desirous of keeping abreast of patented developments in a particular art.

\section{Methodology}

Patent search is known to be a complex, difficult and challenging activity, usually requiring expert Patent Information Specialists to spend a substantial amount of time sourcing (or not) documents relevant to their particular task [15]. This has been however, made less challenging by the growing capabilities of computers and patent analytics tools that have allowed for significant increases in the ability to search the patent data and extract useful information and insights.

To analyse the patents filed at ARIPO from January 2015 to December 2016 the primary source of data was the digital ARIPO Journal. The researcher identified the application numbers of the first patent application filed according to ARIPO Journal Vol. XXXII, No. 1 of 31 January 2015 and the last patent application filed according to ARIPO Journal Vol. XXXIII, NO. 11 of 30 November 2016. This provided the range of application numbers up to 30 November 2016 so the researcher had to manually search for any recorded patent applications using the ARIPO IP Digital Library platform. The digital library also provided the bibliographical information for each patent application filed according to the identified application numbers. This information was then manually recorded on Google Sheets delimited to the four variables highlighted earlier in this paper.

Google Sheets is a Web-based application that allows users to create, update and modify spreadsheets and share the data live online. The Ajax-based programme is compatible with Microsoft Excel and CSV (comma-separated values) files. Spreadsheets can also be saved as HTML [16]. Google Sheets is also free spreadsheets software available to Google subscribers. It allows you to download add-ons that assist with cleaning data, create your own, and write custom code and it is automatically saved in the cloud, attached to your Google account, and accessible from any computer with a browser. For effective patent analytics and visualisation 
An Analysis of Patents Filed at African Regional Intellectual Property Organisation (ARIPO) from January 2015 to December 2016 for Research Intelligence Signalling Using Open Source

Patent Analytics 5

the researcher employed additional open source software by exporting the developed and cleaned spreadsheet to Tableau Public. Tableau Public is streamlined visualisation software that allows one to transform data into a wide range of customisable graphics. Its three-step work flow-Open, Create and Share-allows users to import data and layer multiple levels of detail and information into the resulting visualisations. Ideal for web based publication, it ultimately allows users to merge multiple visualisations onto a single page and export their work as embeddable graphics [17].

\section{Analysis and Results}

The results obtained from the identification of patent application numbers of the said period show that patent applications filed range from application number $\mathrm{AP} / \mathrm{P} / 2015 / 008182$ to $\mathrm{AP} / \mathrm{P} / 2016 / 009607$. However, when the researcher was developing the spreadsheet he discovered that some patent applications would appear in the Journal but were missing in the IP Digital Library. These entries were therefore, cleaned by Google Sheets resulting in 949 patent applications filed for the purpose of this study. The IPC data type was also reduced to sub classes. Sub classes are the third hierarchical level of the classification where each subclass symbol consists of the class symbol followed by a capital letter and the subclass title indicates as precisely as possible the content of the subclass.

The analysis of the applicants/owners of the patents filed at ARIPO from January 2015 to December 2016 show that the most frequent applicant/owner was Qualcomm Incorporated which filed 30 patent applications constituting 3.2 percent of the total patents filed. Of these patents filed a third (10) of them were classified as H04W: Wireless Communication Networks and Telefonaktiebolaget Lm Ericsson (Publ) had two patent applications in the same technological field. A sixth (5) of Qualcomm's patent applications filed was classified as H04N: Pictorial Communication e.g. Television and Telefonaktiebolaget Lm Ericsson (Publ) also has another two patents filed in this area of technology. This shows us that the two applicants are serious competitors. The second highest applicant/owner in terms of patents filed was Bayer Pharma Aktiengesellschaft which had 29 patent applications filed constituting 3.1 percent of the total. Nearly 50 percent of the total applicants/owners had only a single patent application. Fig 1 shows the Top Seven Applicants/ Owners. 


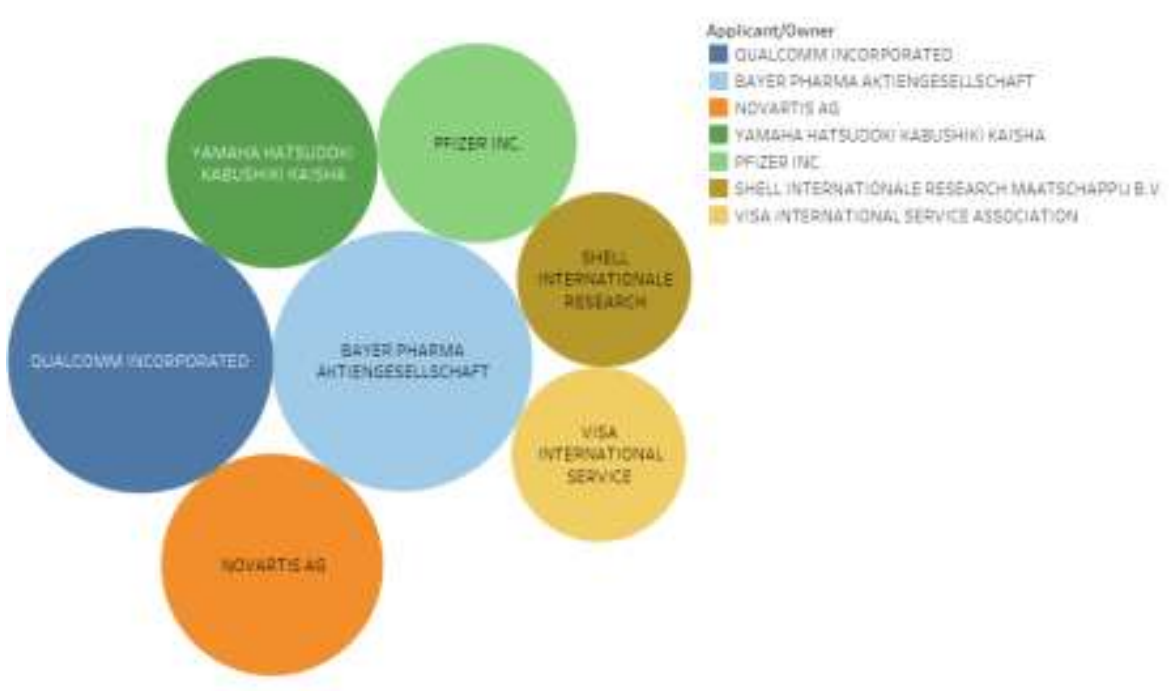

Fig. 1. Top Seven Patent Applicants/Owners

A further analysis of the data was done to reveal patents filed by universities and research institutions. The results show that the highest number of patent applications came from South African universities and research institutions. Stellenbosch University had seven patent applications four of which were filed in 2016 becoming the highest followed by the University of Pretoria which filed six applications. The Council of Scientific and Industrial Research (CSIR) and the University of Witwatersrand had two patent applications while North-West University, Rhodes University and University of South Africa had a single patent application each. See Table 2 for a detailed description of patents filed by South African universities and research institutions. 
An Analysis of Patents Filed at African Regional Intellectual Property Organisation (ARIPO) from January 2015 to December 2016 for Research Intelligence Signalling Using Open Source

Patent Analytics 7

Table 2. Patents Filed by South African Universities and Research Institutions

\begin{tabular}{|c|c|c|c|}
\hline Application No. & IPC & Title & Applicant/Owner \\
\hline $\mathrm{AP} / \mathrm{P} / 2016 / 009538$ & G01N & $\begin{array}{l}\text { A Method For } \\
\text { Diagnosing Tuberculous } \\
\text { Meningitis }\end{array}$ & Stellenbosch University \\
\hline $\mathrm{AP} / \mathrm{P} / 2016 / 009503$ & F28D & $\begin{array}{l}\text { Thermal Energy Storage } \\
\text { Facility }\end{array}$ & Stellenbosch University \\
\hline $\mathrm{AP} / \mathrm{P} / 2016 / 009427$ & G01N & $\begin{array}{l}\text { Method For Diagnosing } \\
\text { Tuberculosis }\end{array}$ & Stellenbosch University \\
\hline $\mathrm{AP} / \mathrm{P} / 2016 / 009398$ & $\mathrm{~A} 01 \mathrm{~N}$ & $\begin{array}{l}\text { Plant Growth Promoting } \\
\text { Rhizobacterial Strains } \\
\text { and Their Uses }\end{array}$ & University Of Pretoria \\
\hline $\mathrm{AP} / \mathrm{P} / 2016 / 009145$ & G01G & $\begin{array}{l}\text { Vehicle } \quad \text { Overload } \\
\text { Management System }\end{array}$ & North-West University \\
\hline $\mathrm{AP} / \mathrm{P} / 2016 / 009131$ & $\mathrm{~A} 61 \mathrm{~F}$ & $\begin{array}{l}\text { Frame Supported Height } \\
\text { Adjustable Pylon }\end{array}$ & Stellenbosch University \\
\hline $\mathrm{AP} / \mathrm{P} / 2016 / 009130$ & A61K & $\begin{array}{ll}\text { Supporting } & \text { Frame } \\
\text { Assembly } & \\
\end{array}$ & Stellenbosch University \\
\hline $\mathrm{AP} / \mathrm{P} / 2016 / 009126$ & A61B & $\begin{array}{l}\text { Audiometry System and } \\
\text { Method }\end{array}$ & University of Pretoria \\
\hline $\mathrm{AP} / \mathrm{P} / 2016 / 009014$ & $\mathrm{C} 12 \mathrm{~N}$ & $\begin{array}{l}\text { Method For Treating HIV } \\
\text { Infection }\end{array}$ & $\begin{array}{l}\text { University of The } \\
\text { Witwatersrand, } \\
\text { Johannesburg }\end{array}$ \\
\hline $\mathrm{AP} / \mathrm{P} / 2015 / 008879$ & G01N & $\begin{array}{l}\text { A Method of Diagnosing } \\
\text { Tuberculosis }\end{array}$ & University of Pretoria \\
\hline $\mathrm{AP} / \mathrm{P} / 2015 / 008485$ & $\mathrm{C} 02 \mathrm{~F}$ & $\begin{array}{l}\text { Method and Apparatus } \\
\text { For Treating A Fluid }\end{array}$ & $\begin{array}{l}\text { University of South } \\
\text { Africa }\end{array}$ \\
\hline $\mathrm{AP} / \mathrm{P} / 2015 / 008422$ & F24J & $\begin{array}{l}\text { A Support Structure For } \\
\text { Multiple Heliostats }\end{array}$ & Stellenbosch University \\
\hline $\mathrm{AP} / \mathrm{P} / 2015 / 008421$ & B63C & A Shark Barrier & Stellenbosch University \\
\hline $\mathrm{AP} / \mathrm{P} / 2015 / 008399$ & A23L & $\begin{array}{l}\text { Extract From Morigaceae } \\
\text { and a Method To Prepare } \\
\text { The Extract }\end{array}$ & $\begin{array}{l}\text { University of The } \\
\text { Witwatersrand, } \\
\text { Johannesburg }\end{array}$ \\
\hline $\mathrm{AP} / \mathrm{P} / 2015 / 008321$ & $\mathrm{C} 02 \mathrm{~F}$ & $\begin{array}{l}\text { A Novel Fluidised Bed } \\
\text { Reactor For Treatment of } \\
\text { Waste Water }\end{array}$ & $\begin{array}{l}\text { Council of Scientific \& } \\
\text { Industrial Research }\end{array}$ \\
\hline $\mathrm{AP} / \mathrm{P} / 2015 / 008281$ & $\mathrm{~A} 61 \mathrm{~K}$ & Oral Care & University of Pretoria \\
\hline $\mathrm{AP} / \mathrm{P} / 2015 / 008280$ & A61K & Skin Care & University of Pretoria \\
\hline $\mathrm{AP} / \mathrm{P} / 2015 / 008263$ & $\mathrm{C} 07 \mathrm{H}$ & $\begin{array}{l}\text { Analysis of } \text { Human } \\
\text { Immune Status }\end{array}$ & Rhodes University \\
\hline $\mathrm{AP} / \mathrm{P} / 2015 / 008256$ & H04W & $\begin{array}{lr}\text { A Method And System: } \\
\text { Back-Tracking } & \text { Forward- } \\
\text { Looking } & \text { (BTFL) } \\
\text { Dynamic } & \text { Channel } \\
\text { Allocation } & \text { Mechanism } \\
\text { For White } & \text { Space Radio } \\
\text { Networks } & \\
\end{array}$ & Csir \\
\hline $\mathrm{AP} / \mathrm{P} / 2015 / 008200$ & A61K & $\begin{array}{l}\text { A Liposomal } \\
\text { Composition Comprising } \\
\text { A Sterol-Modified Lipid } \\
\text { And A Purified } \\
\text { Mycobacterial Lipid Cell } \\
\text { Wall Component And It's } \\
\text { Use In The Diagnosis of } \\
\text { Tuberculosis }\end{array}$ & University of Pretoria \\
\hline
\end{tabular}


It can be noted that Stellenbosch University and the University of Pretoria filed patent applications on the method of diagnosing tuberculosis. This signals to researchers a valuable area of research.

The results further show that 12.8 percent of patent applications filed at ARIPO from December 2015 to January 2016 were classified under IPC Code C07D: Heterocyclic Compounds. This technology field is dominated by pharmaceutical companies and researchers can identify potential industry collaborators. See Figure 2 for visualisation of applicants/owners who filed patents in IPC C07D.

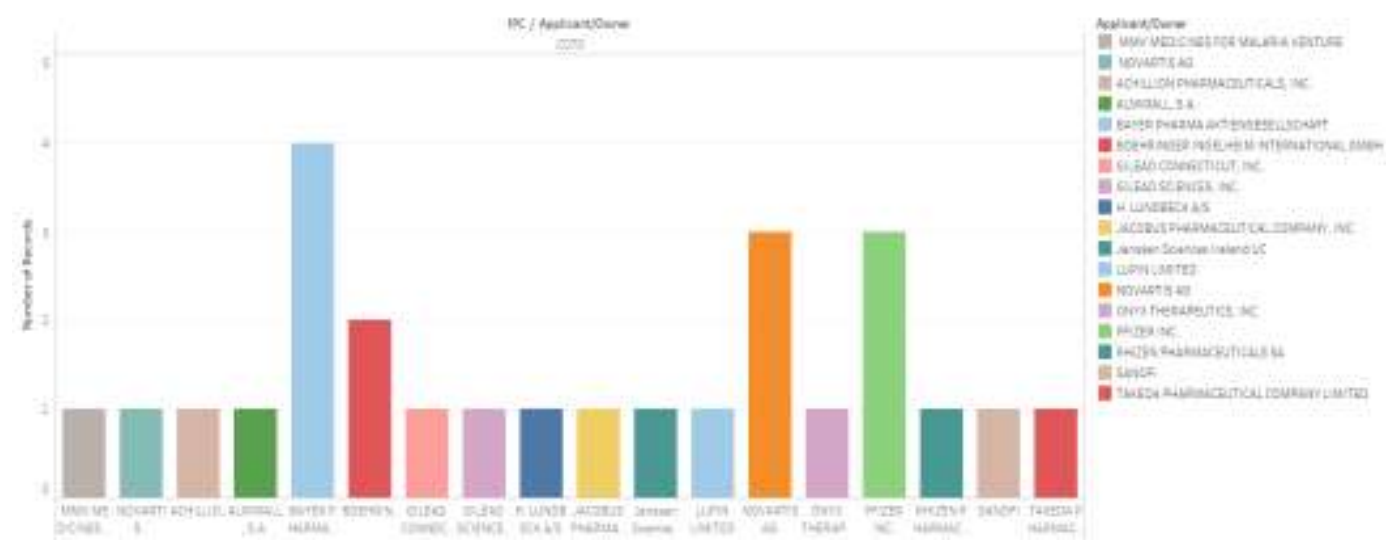

Fig. 2. Applicants/Owners with Patents Classified under IPC C07D

The second highest in terms of IPC Code frequencies is A61K: Preparations for Medical, Dental, or Toilet Purposes. This particular class constituted 9.1 percent of the total. Figure 4 shows an outline of IPC frequencies.

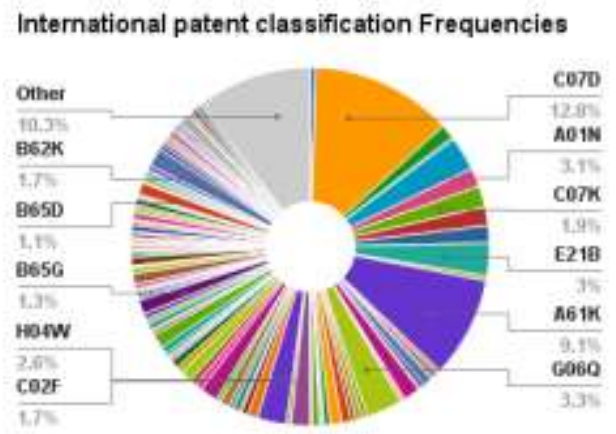

Fig. 3. IPC Frequencies 
An Analysis of Patents Filed at African Regional Intellectual Property Organisation (ARIPO) from January 2015 to December 2016 for Research Intelligence Signalling Using Open Source

Patent Analytics 9

\section{Conclusion}

This paper is a reflection of the wealth of information contained in patents. An analysis of such information is important in research intelligence signalling where resources can be efficiently directed towards relevant research especially to developing countries' researchers who are resource constricted. Open source patent analytics are a useful tool in analysis for developing countries because of their less cost and accessibility. The paper also contributes to awareness raising of the importance of patent information to researchers.

\section{References}

1. WIPO Guide to Using Patent Information, http://www.wipo.int/edocs/pubdocs/en/patents/434/wipo pub 1434 03.pdf

2. http://wiki.piug.org/pages/viewpage.action?pageId=34439448

3. The Role of Patent Information in Supporting Innovation, http://www.wipo.int/edocs/mdocs/sme/en/wipo_smes_rom_09/wipo_smes_r om 09 e workshop02 1-related1.pdf

4. Sweeny, E (2016) Using Patent Information for Strategic Intelligence, Dublin

5. Schmookler, J (1966) Invention and Economic Growth. Harvard University Press, Cambridge, Mass.

6. ------ (1972) Patents, inventions and economic change and selected essays, ed. Z. Griliches and L. Hurwicz. Cambridge, Mass.: Harvard University Press.

7. Beggs, J. J (1981) The dynamic interaction between industry level profits and research and development. Cowles Foundation Discussion Paper no. 588. Yale University.

8. Godin B, Lane JP (2013) "Pushes and Pulls": The History of the Demand Pull Model of Innovation, Project on the Intellectual History of Innovation Working Paper No. 13

9. U.S Department of Commerce.: Technology Assessment \& Forecast, Eighth Report (1977)

10. Benson CL, Magee CL.: Quantitative Determination of Technological Improvement from Patent Data, PLos ONE 10(4): e0121635. doi:10.1371/journal.pone.0121635 (2015)

11. Handbook on Industrial Property Information and Documentation, http://www.wipo.int/export/sites/www/standards/en/pdf/03-09-01.pdf

12. Glossary of Patent Terminology, https://www.oecd.org/sti/scitech/37569498.pdf

13. About the IPC, $\underline{\text { http://www.wipo.int/classification/ipc/en/preface-html }}$

14. Handbook of Industrial Property Information and Documentation, http://www.wipo.int/export/sites/www/standards/en/pdf/03-15-01.pdf 
15. Joho, H., Azzopardi, L., \& Vanderbauwhede, W. (2010). A survey of patent users. Proceedings of the third symposium on Information interaction in context. pp. 13-22.

16. http://searchmicroservices.techtarget.com/definition/Google-Spreadsheets

17. Intro to Digital Humanities, http://dh101.humanities.ucla.edu/?page $\mathrm{id}=163$ 